folk/ed. Derg, 2021; 27(3)-107. say1

DOI: $10.22559 /$ folklor. 1591

\title{
"Bindiği Dalı Kesmek": Türk Dünyası Folklorunda Eş ve Benzer Yaratmalara Nasıl Yaklaşılmalı?
}

\author{
"Man Sitting on Branch of Tree Cuts it off": \\ How to Approach to Variations in Folklore of Turkic World?
}

\section{Cemalettin Yavuz*}

\begin{abstract}
Öz
Bu çalışmada, Türk Dünyası folklorunda karşılaşılan benzer durumlara nasıl yaklaşılması gerektiği konusu sorgulanmıştır. $\mathrm{Bu}$ bağlamda karşılaştırma yönteminin, bütüncül yaklaşımın ve mikro ölçekteki ortaklıklara odaklanmanın önemine vurgu yapılmıştır. Tür, tipoloji, varyant, versiyon gibi kavramların ve analitik araçların sınırlılıklarına, çok boyutlu ve esnek yaklaşımların önemine dikkat çekilmiştir. Buna dayalı olarak Lauri Honko'nun önerdiği karşılaştırma modeli temelinde, Türk Dünyası folklorunda yaygın olarak karşılaşılan bir örnek, ekolojik, tarihî ve fenomenolojik boyutlarıyla incelenmiştir. Farklı kahramanlara atfedilen, metin olarak -tür, hacim, epizot, motif sayısı, dil- oldukça farklılaşabilen anlatıları birbirine bağlayan ortak nokta tespit edilmiştir. Coğrafi olarak birbirinden
\end{abstract}

Geliş tarihi (Received): 19.12.2020 - Kabul tarihi (Accepted): 25.06.2021

Arş. Gör. Dr., Trakya Üniversitesi Edebiyat Fakültesi Türk Dili ve Edebiyatı Bölümü (Trakya University Faculty of Letters Department of Turkish Language and Literature ) Hoca Ahmet Yesevi Uluslararası Türk-Kazak Üniversitesi, Türkoloji Araştırma Enstitüsü Türkistan/ Kazakistan. (Hoca Ahmet Yesevi International Turkish-Kazakh University, Turkology Research Institute Turkistan/ Kazakhstan).yavuzcemalettin@gmail.com. ORCID 0000-0001-6295-21-79 
uzak ya da yakın çeşitli Türk topluluklarının sahip oldukları kendine özgü niteliklerin, folklorik üretim üzerindeki etkisi ortaya konmuştur. Sosyokültürel, tarihî, dinî ve ekolojik faktörlerin ortak bir olgu çerçevesinde çeşitli toplulukları nasıl farklılaştırdığı ya da benzer kıldığg gösterilmiştir. Türk Dünyası folkloru araştırmalarında yöntem konusunun tartışılmaya devam etmesi, birikmeye devam eden verilerin dijital çağın imkânlarını etkin bir şekilde kullanmaya elverişli ortak ve büyük bir platformda toplanmasına dönük çalışmaların yapılması önerileri getirilmiştir.

Anahtar sözcükler: Türk Dünyası folkloru, karşılaştırma yöntemi, çeşitlemeler

\begin{abstract}
In this study, I examine the issue of how to approach similar cases encountered in Turkic World folklore. In this context, I emphasize the importance of comparison method, holistic approach and focusing on micro-scale common grounds, also remark the limitations of concepts such as genre, typology, variant, version and analytical tools and the importance of multi-dimensional and flexible approaches. Accordingly, based on the comparative model proposed by Lauri Honko, I analyze a case -commonly encountered in Turkic World folklore- with its ecological, historical and phenomenological dimensions. Determining the common point that connects the narratives which are quite differentiated in terms of text -genre, size, episode, number of motifs, language- and are attributed to different characters, I try to reveal the effect of the unique characteristics of various Turkic peoples that are geographically distant or close to each other, on folkloric production, and to show how socio-cultural, historical, religious and ecological factors differentiate or make similar communities within the framework of a common phenomenon. Finally, I suggest that the methodology of the folklore researches of the Turkic World should continue to be discussed, and studies should be carried out to collect the accumulated data in a common and large platform that is convenient to use the possibilities of the digital age effectively.
\end{abstract}

Keywords: folklore of Turkic world, comparison method, variations

\title{
Extended summary
}

In this study, I examine the issue of how to approach similar cases encountered in Turkic World folklore. Within this context, I emphasize the importance of comparison method, holistic approach and focusing on micro-scale common grounds, also remarks the limitations of analytical tools and concepts such as genre, typology, variant, version, etc. and the importance of multi-dimensional and flexible approaches.

The variations I examined are attributed to Nasreddin Hodja in most of the Turkic world. Therefore, firtly I identified the limitations arising from the existing analytical tools in the studies on Nasreddin Hodja. Authors of those studies accept Nasreddin Hodja as a historical 
figure who lived in Anatolia in the $13^{\text {th }}$ century and seek the name of Nasreddin Hodja in the folklore of other Turkic peoples in order to approach Turkic folklore in a holistic manner.

While basing on the presence of the names "Nasreddin", "Apandi", "Nasir" etc. -sometimes additionally Hodja's wisdom and priesthood- in any narrative in the determination and analysis of Nasreddin Hodja anecdotes, they associate Nasreddin Hodja with similar narrative characters of other Turkic peoples or ignore some of them. On the other hand, they don't focus on any idea or method regarding the variations and characters of narratives that became famous with the name of Nasreddin Hodja in some Turkic peoples, which we may encounter even in other Turkic peoples' or different nations' cultures - outside the area of direct contact.

The present study determines the common point that connects the narratives which are quite differentiated in terms of text -genre, size, episode, number of motifs, language- and are attributed to different characters. Accordingly, on the basis of the comparative model proposed by Lauri Honko, the variations determined in Turkic World folklore and different cultures are analyzed in terms of ecological, historical and phenomenological dimensions.

I conduct the ecological analysis within the framework of Chuvash folklore. Although Nasreddin Hodja is not mentioned, related variations attributed to him entered Chuvash folklore through the Tatars. Also, this relationship is not uni-channeled or unrepeatable. The variations that enter Chuvash folklore have been ecotypificated and recreated within the tradition. However, Nasreddin Hodja and his anecdotes could not become a great tradition in Chuvash folklore as in Tatar folklore. Because both the traditional beliefs of the Chuvash people and the shift in the direction of the cultural interaction channel have had negative effects on the ecotypification and spreading processes. On the other hand, the absence of major deviations in the short or long variations encountered in Turkey, also in Tatar, Kazakh and Uzbek cultures, indicates the decisive role of the religious factors.

Then, I analyze a variation compiled from the Muslim Pashtuns in terms of tradition history, which reveals that the variation in Pashtun is no different from its counterparts in the Turkic World culture, except for the weaver and the Seyit character. These differences are substrate elements, but they have been successfully adapted to the superstrate properties. Therefore, the reason why the Chuvash variations have lost their superstructure features in ecotipification process in tradition is questioned and concluded that Pashtuns know and maintain the post-death beliefs of Islamic view. In this context, they share a common point with Turkic peoples such as Turks, Kazan Tatars, Kazakhs and Uzbeks.

Phenomenological dimension analysis includes variations belonging to Indian culture in the study, as well. These narratives, which can differ in structure, texture and volume, are detected share a number of units and identical units. Some structural units are found to be common in all variations examined. According to this, situations such as coldness in the hand and face, farting, burping, halting or stumbling of the horse are presumed to be the signs of death and the heroes have assumed themselves to be dead through believing these presumptions. The acts of assuming himself dead and returning to reality take place sometimes 
in a grave, sometimes next to a river or on a bridge over a river, or as in a single example - the Paramartha Guru - in bed and water. All these places are known to be associated with the uterus in mythological context and thus constitute a threshold / transition point between death and birth. The transition of the hero into reality is accomplished through symbolic punishment methods such as flogging, having his donkey eaten by wolves, being robbed by thieves or plunging into the water. Cutting the branch while sitting on it and acting on the basis of irrational predictions or assuming himself dead can be regarded as other equal units. Therefore, the meaning of all these narratives can be summarized as death - breaking away from reality - and being reborn through punishment - returning to reality. Thus, these heroes push the boundaries between folly and wisdom, fantasy and reality, and (social) structure and anti-structure, and reveal the relationships between opposing structures and roles using the power of humor and critical thinking.

\section{Giriş}

$\mathrm{Bu}$ çalışmanın amacı, Nasreddin Hoca'ya mâl edilen ve "Bindiği dalı kesmek" şeklinde dilimizde deyimleşmiş bir ifadeye de dönüşmüş olan anlatı örnekleminde, Türk Dünyası'ndaki kültür dairelerinde karşımıza çıkan benzer durumların nasıl değerlendirilmesi gerektiğine dair bir inceleme modeli oluşturmaktır. Belirtmek gerekir ki tarihsel derinlik ve coğrafi yayılma sahası bakımından Türk Dünyası'nın son derece girift ve çeşitlilik arz eden yapısından dolayı Türk Dünyası'na dönük her araştırma gibi tek bir örneğe odaklanmış olan bu çalışma da birçok zorluğu içinde barındırmaktadır. Dolayısıyla bu çalışmayı bir vaka incelemesi ve yaklaşım denemesi olarak nitelemek yerinde olacaktır.

Ele alacağımız örnekler, Türk Dünyası'nda büyük bir yaygınlığa sahiptir ve içerik bakımından değişkenlik göstermektedir. Bazılarında "bindiği dalı kesmek" gibi en temel motife bile rastlamasak ${ }^{1}$ da çeşitlenmenin kaynağı olan bir noktayı ortaklaştıklarını görüyoruz: "Öldügünü sanmak." O hâlde bu metinleri eş yahut benzer olmadıklarını düşünüp birbirinden bağımsız mı değerlendirmeliyiz? Bu motifin Hintli Kalidas'a ve Pançatantra'daki Paramarta Guru'ya atfedilen örneklerine de rastliyoruz. Bazılarında Nasreddin Hoca'nın adı bile geçmese de 1875 tarihli Pakistan'da Peştunca konuşan Müslüman bir topluluktan derlenen anlatının Nasreddin Hoca'ya atfedilen anlatıyla neredeyse tamamen aynı olduğunu görüyoruz. Bütün bu karışıklık ve zorluklar karşısında nasıl bir tavır almalıyız? Daha da önemlisi bütün bu veriler Türk Dünyası ve folkloru açısından bize ne söyleyebilir?

Diğer bir mesele ise ele alacağımız anlatıların birbirlerine nispetle benzerlik yahut farklılıklarıdır. Başlıkta kullandığımız "Eş ve Benzer” ifadesi bir genelleme olup anlatılar arasında bir ayrım ya da tasnif yapma yoluna gidilmeyecektir. Bu tercihin altında birtakım nedenler bulunmaktadır. Öncelikle, "eş metin" (varyant) ve "benzer metin" (versiyon) kavramlaştırmaları büyük oranda görelilik arz eder. Öyle ki herhangi iki folklor yaratması arasındaki benzerlik ya da farklılı̆̆ tayin edebilecek kriterler oluşturmak pek mümkün görünmemektedir. Türk folkloru bağlamında varyant ve versiyon kavramlaştırmalarının getirdiği diğer zorluklar dile getirilmiş olsa da konuyla ilgili net bir çözüm önerisi yerine 
performans merkezli çalışmaların teşvik edilmiş olduğu görülmektedir. Performans temelli çalışmaların önemini azımsamamakla birlikte bu bağlamda yapılacak çalışmalar tabii olarak tarihsel sürecin son halkasına odaklanacaktır. Ne var ki çalışma alanı olarak Türk Dünyası folklorundan bahsedilecekse tarihsel sürecin ve mukayese yönteminin kenara itilemeyecek kadar önemli olduğuna kimsenin itirazı olmayacaktır. Bu durumda halkbilimcilerin yöntemlerini sınırlandırmak yerine daha çok çeşitlendirmesi ve güncellemesi gerektiği sonucu ortaya çıkmaktadır.

Bu çalışmada, ele alacağımız anlatıları kronolojik düzlemde gerileyici (regressive) değil, ilerleyici (progressive) bir yaklaşımla inceleyerek Türk Dünyası topluluklarının münferiden ve birlikte geçirmiş olduğu sosyokültürel değişiklikleri anlamada ve böylece günümüze 1şık tutacak veriler elde etmede kullanılacak argümanlar olarak görmenin önemine vurgu yapacağız. Diğer taraftan bu çalışmada kullanılan anlatıların form bağlamında bütünlüğü ya da benzerliği ön planda tutulmayacaktır. Çünkü metin bütünlüğünü öncelemek, araştırmaciyı yine "ur-form" yahut "ur-type" arayışına götürecek ve bütünlüklü yaklaşıma engel teşkil edecektir.

Türk Dünyası folkloruna bütünlüklü bir yaklaşım geliştirmek adına önemli girişimlerde bulunulmuş olsa da konuya yine metin ölçeğinde yaklaşıldığı görülmektedir. Öcal Oğuz’un (1997) "müşterekleri öne çıkaran, farklılıkları tahlil eden" bir yöntem olarak önerdiği "Millî Mukayese Yöntemi” varyant ve versiyon kavramlarının uygun bir şekilde yeniden biçimlendirilmesi ve Türk kültür coğrafyasının özelliklerini öncelemesi bakımından önemlidir. Oğuz’un varyant ve versiyon kavramlarına eleştirisi, köken ve asıl metin arayışını çağrıştırması ve dolayısıyla bunların Türk Dünyası folkloruna bütüncül yaklaşmanın önünde engel arz etmesindendir. Metin Ekici'nin (1998) konuyla ilgili bir çalışması ve Öcal Oğuz’un (1999) buna karşılık olarak kaleme aldığı ikinci yazısıyla, varyant ve versiyon kavramlarının Türkçeleştirilmesine ve iki kavram arasındaki anlam farklılığının ortaya çıkarılmasına odaklanılarak metin bütünlüğünü ve benzerlik oranını önceleyen yaklaşımın pozisyonu tekrar güçlendirilmiştir.

Sovyetler Birliği’nin dağılmasıyla hız kazanan Türk Dünyası folkloruna dönük ilk dönem çalışmaları için bu yaklaşım gerekli ve önemliydi. Bu yaklaşımla hazırlanan ve hazırlanacak çalışmalar bir anlamda Türk folklorunun demirbaş listelerini ve sonrasında yapılacak çalışmaların temelini oluşturmaktaydı. Artık elimizde bütün Türk boylarıyla ilgili görece çok daha zengin bir birikim bulunmakta ve kaynaklara daha kolay ulaşılabilmektedir. Mehmet Aça'nın (2000) alp tipiyle ilgili bütüncül yaklaşımı ve önerileri, araştırma konusunun çerçevesini daraltmak, coğrafyayı genişletmek ve metinsel benzerlik ya da yüzeysel sosyokültürel özelliklere dayalı benmerkezci bakış açısını reddetmek bakımından Türk folklor araştırmalarında ikinci bir aşama olarak kabul edilebilir. ${ }^{2} \mathrm{Ne}$ var ki alp tipi veya destan türü de bütün Türk boylarının folklorunda bulunmaz. Bunlar bize Türk folklor araştırmalarında bütün Türk kültür coğrafyalarını kapsayacak şekilde daha küçük ortaklıkları önceleyen üçüncü bir boyuta ihtiyacımız olduğunu göstermektedir.

Burada dikkat çekmek istediğimiz nokta, bütün Türk coğrafyasında Nasreddin Hoca 
adını ya da benzer tipleri ve metinleri aramak yerine, benzer düşünce ve yaratma ya da yeniden yaratma biçimlerinin tarihsel ve sosyokültürel bağlamda sorgulanması gerektiği meselesidir. Aksi takdirde Nasreddin Hoca adını bilmeyen Türk boylarını "Türk Dünyası" kavramlaştırmasının dışında bırakabilir ya da bütün bir Türk kültür coğrafyasında sonsuz defa yeniden yaratılıp aktarılmış bir anlatının kökenini başka bir medeniyet dairesine dayandırmak zorunda kalabiliriz. Daha da önemlisi, “Türk Dünyası'nın zengin çeşitliliği ve çok basamaklılığı karşısında etnik, dil ve kültürel benzerlikleri aynı anda içine almayı amaçlayan, nihayetinde popüler, kuzeybatı Avrupa kökenli bir halk kavramının çabucak iflas etmek durumunda" (Johanson 2001: 173) kalacağı gerçeğini gözden kaçırabiliriz. Johanson'un temkinli de olsa “Türk Dünyası'nı hiçbir ortak kültür örneği birbirine bağlamıyor.” şeklindeki yargısı, ancak sözünü ettiğimiz mikro ölçekteki olguların incelenmesiyle doğrulanabilir ya da çürütülebilir. Yine de Türk Dünyası'nı tek bir örnekle birbirine bağlamak zorunda değiliz. Önemli olan kültür dairelerinin birbiriyle ve bütün olarak dış dünyayla olan farklılık ve benzerliklerinin doğru bir şekilde anlaşılmasıdır.

İnceleyeceğimiz anlatılar metin bütünlüğünü ya da ortaklaşan bir kahraman adını haiz değilse de toplu hâlde bakıldığında bütünlük arz etmektedirler. Mikro ölçekteki ortaklıklar üzerine odaklanmak Türk Dünyası folklor araştırmalarına önemli bir işlevsellik ve daha kuşatıcı bir nitelik kazandıracaktır. Nasreddin Hoca adına bağlanan anlatılara da bu şekilde yaklaşılması gerektiği düşüncesindeyiz. Örneğin, Nasreddin Hoca adı, Türk Dünyası'nda yazılı kültür ve İslam inancıyla yakından ilişkilidir. ${ }^{3}$ Ancak diğer topluluklarda da benzer anlatılar bulunabilir ve bunlar aynı veya farklı düşünce ve algılama biçiminin ürünleri olabilirler. Üstünde durulması gereken nokta, benzerlikler ya da farklılıkların açıklanması olmalıdır. Çalışmalar sadece metin ya da belirli kahramanın adı üzerinde odaklanırsa Türk Dünyası'nın birçok unsuru çerçevenin dışında kalacaktır. Bu nedenle başlıkta kullandığımız "yaratma" ifadesi bilinçli bir tercihtir. Bizim örneklemimizde bu yaratma belli bir motif etrafında şekillenmiş anlatılardır. Türk folkloruyla ilgili başka çalışmalarda bu yaratma başka bir motif, bir düşünce kalıbı, bir inanış, ritüel, ideoloji, sanat ürünü, estetik bir unsur ya da bir ezgi olabilir.

\section{Yöntem}

Lauri Honko, 1986 yılında karşılaştırmalı analiz ve çeşitlenme (variation) teorisinin folklor çalışmalarındaki merkezî konumuna ve bu konuda yetkin bir teorinin bulunmadığına dikkat çekerek geleneksel Fin metodunun metin kritiği yaklaşımını bir çıkmaz sokak olarak nitelemiş; yapı, performans, kompozisyon kuralları ve gelenek üretimi, tür odaklı iletişim, bağlam, işlev, anlam gibi folklor tartışmalarının karşılaştırmalı analiz ve varyasyon teorisi üzerinde tam olarak etkili olması gerektiğini vurgulamıştır. Buna dayalı olarak kültürlerarası (intercultural) ve kültür içi (intracultural) düzeyde art zamanlı (diachronic) ve eş zamanlı (synchronic) etkenleri göz önünde bulunduran üç boyutlu bir karşılaştırma önermiştir: Gelenek fenomenolojisi, gelenek tarihi, gelenek ekolojisi (Honko, 1986: 105-124).

Honko'nun teorisi Türk Dünyası folkloru araştırmaları açısından önemli ilkelere sahiptir. 
Bununla birlikte aradan geçen 35 y1l ve bu süreçteki sosyokültürel, teknolojik, bilimsel değişiklikler ve ilerlemelerle Türk topluluklarının kendine özgü dinamikleri de elbette inşa edilmesi gereken yaklaşım ve yöntemler için önemli değişkenleri meydana getirmektedir. Biz burada sadece kendi araştırma konumuz ve eldeki veriler çerçevesinde yaklaşım ve değerlendirmeler geliştireceğiz.

Honko'nun gelenek ekolojisi boyutu olarak nitelediği mukayese biçimi, kültür içi çeşitlenmeler ve gelenekleri anlamaya dönüktür. Bu karşılaştırma sürecinde bir geleneğin bizzat kendisi, onu sürdüren topluluk ve bu ikisini kuşatan doğal evren söz konusu geleneğin içinde bulunduğu emik sistemi ortaya çıkarmak için sorgulanır (Honko, 1986: 114-117).

$\mathrm{Bu}$ bağlamda Çuvaş folklorunda karşılaştığımız bir gelenek için herhangi bir yerleşim yeri ya da İdil-Ural bölgesinin tamamı ekolojik araştırma bölgesinin içine girmektedir. Dolayısıyla Tatar ve Başkurt gibi Türk topluklarının yanı sıra Rus ve Fin-Ugor (Mari, Udmurt, Mordvin) gibi farklı etnik kökene sahip toplulukların meydana getirdiği kültürel çevre ${ }^{4}$ herhangi bir Çuvaş geleneğinin incelenmesinde önemlidir. Söz konusu unsurun nasıl yerelleştirildiğini (ecotypification) $)^{5}$ ve sosyokültürel değişiklikleri anlamak art zamanlı ve eş zamanlı karşılaştırmalarla mümkündür. Bu çalışmada yalnızca Çuvaş folklorundaki çeşitlenmeler -elbette çeşitli karşılaştırmalar yaparak- ekolojik boyutta -gelenek, topluluk ve doğal çevre bağlamında- değerlendireceğiz.

Honko'nun güncellemeye çalıştığ diğer bir karşılaştırma biçimi, kültürlerarası çeşitlenmeleri inceleyen ve Fin metoduyla özdeşleşmiş olan gelenek tarihi (tradition history) meselesidir. Bir gelenek herhangi iki kültür arasında ödünçlenebilir. Bu durumda sorgulanması gereken ödünçlemenin yönü -kimin kimden aldığ1- değil, ödünçlenen olgunun doğası ve bunun alıcı kültürdeki kullanım biçimidir. Çünkü bu olgu uzun süreli bir etkileşimin sonucu olabileceği gibi yüzeysel bir kopya da olabilir. Bu durumda olgunun alt katman (substrate) ve üst katman (superstrate) özelliklerinin incelenmesi gerekir. (Honko, 1986: 120-122).

Türk kültür çevrelerinde Keloğlan olarak tanıdığımız masal tipinin bir benzeri Çuvaş folklorunda Kel İvan (Kukşa İvan) olarak karşımıza çıkmaktadır. Kukşa İvan anlatılarının Rus kültüründeki Ahmak İvan (İvan Durak) anlatılarıyla tip ve tema gibi önemli benzerlikler gösterdiği görülüyor. Ne var ki İvan Durak kel değil. Bu önemli bir alt katman özelliği olmalıdır. Anlatılar üzerindeki ekolojik incelemeler başka alt katman özelliklerini ve FinUgor halklarıyla olan etkileşime dayalı yan katman ${ }^{6}$ (ad-strate) özelliklerini de ortaya çıkaracaktır. Dolayısıyla Çuvaşların Kukşa İvan'ını hem Keloğlan ile hem de Ahmak İvan'la karşılaştırmadan tam olarak anlayamayız. Bu durumun tersten bir okuması, Balkan coğrafyasında oldukça yaygın olan Nasreddin Hoca tipi ve anlatıları üzerinde yapabilir. ${ }^{7}$ Bu çalışmanın konusuyla ilgili olarak Pakistan'ın Banû bölgesinde 1874 yılında derlenmiş Peştunca bir anlatı, bu coğrafyanın geçmişteki Türk kültür çevreleriyle münasebeti bakımından aynı doğrultuda incelenecektir.

Gelenek fenomenolojisi boyutunda ise yapı, içerik ya da işlev bağlamında benzer olan unsurlar, ait oldukları kültürlerin birbirleriyle herhangi bir şekilde teması ya da genetik bağlılığının olup olmadığı dikkate alınmaksızın karşılaştırılır. Bu karşılaştırma, insanlığın 
evrensel özelliklerini, kültürlerin benzer kalıplarını, bir kültürü eşsiz yapan nitelik ve nicelik farklılıklarını ortaya çıkarır. Yapısal işlevler, masal temaları, ritüel kalıpları ve nesneleri gibi unsurlar, fenomenolojik düzeyde yapısal anlamı ortaya çıkarmak için sorgulanabilir (Honko, 1986: 111-115).

Şirazlı Sadi'nin Bostan'ından (bk Duman, 2018: 656) Çuvaş folkloruna, Anadolu'dan Türkistan'a kadar çok geniş bir coğrafyada karşımıza çıkan söz konusu çeşitlemeler 4.-5. yüzyıllarda yaşadığı düşünülen Hintli şair Kalidas'a (Dubey, 2018) ve yine Pançatantra'nın çeşitli çevirilerinde karşılaştığımız Hintli, budala bir rahip olarak tasvir edilen Paramarta Guru'ya (Dubois, 1826: 301-311; Beschi, 1861: 127-174) atfedilen çeşitlemelerinin varlığ1, bu anlatıların fenomenolojik boyutta incelenmesi gerektiğini gösterir. Bu motifler etrafinda şekillenen çeşitlemeler, kültürlerin evrensel karakteristiğinin dışavurumudur. Yine de Stith Thompson'1n (1958) motif kataloğundaki (1240, 1313, 1313A) ve Antti Aarne ile Stith Thompson'1n (1961) masal tipleri kataloğundaki (J2133.4, J2311.1, J2311.1.1, J2311.2) kayıtları incelendiğinde bu anlatıların Nasreddin Hoca fikralarının yayılma sahalarıyla Hindistan'da yoğunlaştığını görmek, yayılma bakımından Hindistan, İran ve Anadolu coğrafyalarındaki derin tarihî ve kültürel ilişkilerin etkilerini yok sayamayacağımıza işarettir. Türk edebiyatındaki Pançatantra, Kelile ve Dimne çevirilerinin yeri ${ }^{8}$ bunun bir başka delilidir.

Türk Dünyası topluluklarının büyük bir çoğunluğunun folklor kategorileriyle ilgili günümüze kadar önemli çalışmalar ve aktarmalar yapılmıştır. Ne var ki bunların bütünlüklü olarak karşılaştırılabilmesi, günümüzün imkânlarına uygun bir şekilde hazırlanmış büyük dijital korpusların hazırlanmasını gerektirmektedir. Henüz yeni sayılabilecek bir çalışmada tipolojilerin, türlerin veya diğer metinselleştirme (textualization) araçları ve stratejilerinin eksiklikleri ve riskleri, büyü metinleriyle ilgili çalışmalar üzerinde gösterilmiş; konuyla ilgili ulusal ve uluslararası nitelikte, standartlaştırılmış metinleştirme tekniklerine dayalı, çok boyutlu ve karşılaştırmalı sorgulamalara elverişli devasa dijital bir veri tabanının imkânları ve gereklilikleri tartışılarak temel veri ve veri ötesi (metadata) bilgilerin neleri içereceğiyle ilgili bir taslak sunulmuştur (İlyefalvi, 2017). Uzun zaman ve büyük emek gerektireceği kesin olan ve folklorun bütün kategorileri için oluşturulması gereken böyle bir alt yapı yeni ufuklar açacaktır. ${ }^{9}$

\section{Gelenek ekolojisi boyutu}

Türkiye'deki Nasreddin Hoca fıkraları ile ilgili çalışmaların ağırlık merkezini onun tarihî kişiliği ve memleketi meselesi oluşturmuştur. Bu araştırmaların tarihçi ya da edebiyat tarihçisi ve halkbilimci olmak üzere iki temel bakış açısına dayandığı anlaşılmaktadır (bk. Görkem 2012). Her ne kadar iki grubun da birbirine dönük eleştirileri olsa da bazı noktalarda birleştikleri görülmektedir ki biz konumuz itibariyle bu noktalara odaklanmak istiyoruz. İki gruptaki araştırmacılar da Nasreddin Hoca’yı 13. yüzyılda Anadolu'da yaşamış bir tarihî şahsiyet kabul etmekte ve Türk folkloruna bütüncül yaklaşabilmek adına diğer Türk boylarının folklorunda -farklı bakış açılarıyla da olsa- Nasreddin Hoca adını aramaktadırlar. Diğer bir ifadeyle onu belli bir zamana ve mekâna yerleştirmeye çalışırken aynı zamanda 
Türk Dünyası'nın “ortak temsil” yeteneği olan/olması gereken bir anlatı tipi olarak kabul etmektedirler. Hoca’ya bu vasfi yüklerken “Hangi yüzyıl?” ve "Hangi coğrafya?” sorularının üzerinde pek durulmamaktadır. İki gruptaki araştırmacılar da Nasreddin Hoca fikralarının tespiti ve incelenmesinde herhangi bir anlatının "Nasreddin", "Apandi”, "Nasır" vb. adlarını -bazen ek olarak bilgelik ve din adamı olma niteliklerini- taşıyıp taşımadığı kriterini esas kabul ederken, Nasreddin Hoca adını bilmeyen farklı Türk boylarının benzer fikra tiplerini onunla ilişkilendirmekte ya da bu Türk boylarını görmezden gelmeyi tercih etmektedirler. Diğger taraftan iki yaklaşım biçimi de bazı Türk boylarında Nasreddin Hoca adıyla meşhur olmuş anlatıların başka Türk boylarında ya da farklı millet ve -doğrudan temas alanı dışındaki- kültürlerde bile karşılaşabileceğimiz çeşitlemeleri ve tipleriyle -“Bindiği Dalı Kesmek" fikrasında olduğu gibiilgili herhangi bir fikir ya da yöntem üzerinde durmamaktadır. ${ }^{10}$ Bu kabuller ve yaklaşımlar bir takım sorunları ortaya çıkarmaktadır.

Belirtmek gerekir ki Türk boyları arasında ya da dünyada Nasreddin Hoca adının tanınması ile ona atfedilen anlatı ya da motiflerin bilinir olmasının farklı biçimlerde ve zaman dilimlerinde gerçekleşmiş olabileceğini kabul etmek gerekir. Yapılan araştırmalar göstermiştir ki Anadolu'da 13. yüzyıla kadar izini sürebildiğimiz Nasreddin Hoca adının dünyaya açılması İstanbul, Kazan ve Kahire gibi önemli kültür merkezleri üzerinden ve ancak 18. yüzyıldan sonra olmuştur (Boratav, 2006: 83-102; Türkmen, 1987; Kut, 1986). Dolayısıyla İslam ve yazılı kültürün bu yayılma sürecinde etkisi büyüktür. Bu nedenle Çuvaşlar, Altaylar, Hakaslar, Sarı Uygurlar ya da Sahalar gibi Türk boyları Hoca'nın adını hiç bilmezken Balkanlardaki Türk olmayan milletlerin folklorunda birçok Türk topluluğundan daha önce söz konusu fikralar kayıt altına alınmış; ilerleyen süreçte yazılı edebiyat, sinema ve tiyatroya adapte edilmiştir. Hatta günümüzde de bütün dünyada yayılmaya devam etmektedir. ${ }^{11}$ Bütün bunlar Nasreddin Hoca'nın Türk Dünyası'nın ortak değeri olmadığı/olamayacağı anlamına elbette gelemez. Aksine, "Nasreddin Hoca şarkın bütün İslam kavimleri arasında, bilhassa Avrupa ve Asya'nın geniş dağınık sahalarına yayılan Türkler arasında asırlardan beri yaşamış" (2004: 183-184) ve artık günümüzde "eşsiz bir kültürler arası rol üstlenen Türk halk kahramanı" (Sabatos, 2016: 35) olmuştur. Ancak "Türkçenin iletişim dili olduğu her yerde Nasreddin Hoca fikralarının anlatıldığı” (Görkem, 2012: 103) ya da onun adını bilmeyen Türk topluluklarında da bu fikra tipinin "yakın gelecekte asli tip hâline dönüşeceğì" (Özkan, 1999: 18) fikirleri, günümüz ve tarihî süreç bağlamında çok boyutlu yaklaşımlarla tartışılmalıdır. Nitekim bir folklor ürünü bile olmayan, Çuvaş yazarı Kuşma Çulgaş (Kuz'ma Afanas'yeviç Çulgas')'ın (1939) çocuklar için kaleme aldığı avcı hikâyelerinin kahramanı olan Lapşu Ştappani araştırmacılar tarafından (Güngül, 1995: 63; Öğüt-Eker, 2005: 44; Sakaoğlu-Alptekin, 2009: 73) Nasreddin Hoca’yla özdeşleştirilmiştir. Ne var ki Lapşu Ştappani hikâyeleri yazılı edebiyat ürünü olup modern edebiyat ve folklor ilişkisi bağlamında değerlendirilmelidir. Gh. I. Constantin, Çuvaş yazar Yuhma Mişşi'nin Tsvetı El'bi [El'bi'nin Çiçekleri] adlı eserindeki Patyan adlı kahramanın Nasreddin Hoca, Aldar Köse ve Ahmet Akay tipleriyle benzerliklerinin kökenini İstanbul, Kırım, Kazan ve Doğu Türkleri arasındaki kültürel ilişki kanallarını sorgulayarak açıklamaya çalışmıştır (1972: 180-181). Dolayısıyla tespit edilen benzerlik ya da farklılıklara dair açıklamaların sağlam temellere oturtulması gerekir. 
Ele alacağımız anlatıların Çuvaş folklorundaki örneklerine geçmeden önce belirtmeliyiz ki bu çeşitlemeler "öldüğünü sanmak" gibi temel bir motifle birlikte "bindiği dalı kesmek", “ölüm zamanını tahmin etmek", "yellenmek, hapşırmak gibi ölüm belirtileri göstermek”, “öldüğünü kendisi haber vermek”, "köprüden geçmek”, “mezara girmek”, "kendi tabutunu taşıyanlarla konuşma”, “cezalandırılarak/dövülerek canlanmak” gibi ikincil motifler arasından seçilen motiflerin çeşitli kombinasyonlarıyla inşa edilen bir anlatı tipi meydana getirmektedir. Örneğin, 1837 tarihli ilk Nasreddin Hoca fıkraları kitabı olan Letâif’te iki çeşitleme vardır ve bunlardan bir tanesi "bindiği dalı kesmek" motifiyle birlikte "ölüm tahmini”, "öldüğünü sanmak" ve "tabutunu taşıyanlarla konuşma" motifleriyle inşa edilmişken diğeri "mezara düşerek öldüğ̈̈nü sanma", "kervan seyisleri tarafından dövülme/cezalandırılma" ve "canlanma” motiflerini içerir (Koz, 2015: 49, 51). Ancak Mustafa S. Kaçalin'in İstanbul Üniversitesindeki bir yazmada tespit ettiği çeşitlemede bu motiflerin tümü tek bir anlatı meydana getirmektedir (Kaçalin, 1997: 106). Dolayısıyla ilk bakışta kimi çeşitlemeler birbirinden bağımsızmış gibi görünebilir. Şimdi Çuvaş folklorundaki çeşitlemeleri ekolojik boyutuyla ele alabiliriz.

N. İ. Zolotnitskiy’in ünlü Çuvaşça sözlüğünde, Çuvaşlar arasında falcılık ve hekimlik gibi işlevleri bulunan "yumza" (yumış, yumşı) tipinin Sibirya şamanlarıyla karşılaştırıldığı bir ek bulunmaktadır. Burada Çuvaşlar arasında yaygın olarak anlatıldığı ifade edilen anlatıya göre bir Çuvaş ne kadar ömrü kaldığını öğrenmek için bir yumzaya gider ve "Üç kez yellendiğinde öleceksin!” cevabını alır. Çuvaş endişeyle evine döner ve odun kalmadığını görünce ormana gider. Odunları hazırladıktan sonra yorgunluktan dolayı ilk günahını işleyen Çuvaş, zaten korkmaya başlamışken orman bekçisine yakalanır ve yediği dayakla ikinci kez yellenir. Yoluna devam eden Çuvaş, bir bayırda kızağı devrilince bu sıkıntılı durumdan ötürü üçüncü günahı işler ve "İşte öldüm!” diyerek karların üstüne düşer. Bir Rus Kazağı onu bulur ve durumu öğrendikten sonra aptallığından ötürü onu kırbaçlamaya başlar. Çuvaş birden canlanıp ayağa kalkar ama aklını kaybetmiştir (Zolotnitskiy, 1875: 169).

Kısa olmakla birlikte bu anlatının bir ekotip olduğu fikrini destekleyecek içeriğe dair herhangi bir unsur görünmüyor. Yani birazdan ele alacağımız çeşitlemelerin aksine doğal ve kültürel özellikler bakımından haricî hiçbir unsur barındırmıyor. Gerçekten de Çuvaşların yumzalardan ne kadar korktuğu, hastalıklar başta olmak üzere çeşitli konularda varsayımlarına ve tavsiyelerine ne kadar itibar ettikleri iyi bilinmektedir. ${ }^{12}$ Ancak ölüm tahmini, üç kere yellenme, öldüğünü sanma ve dayakla cezalandırma sonucu tekrar canlanma motifleri ele aldığımız çeşitlemelerin en önemli unsurlarındandır. Ayrıca Zolotnitskiy anlatının Çuvaşlar arasında iyi bilindiğini söylese de içinde yumza geçen başka bir çeşitlemeye rastlamadığımızı belirtelim. Diğer taraftan Zolotnitskiy, Kazan Üniversitesinde okumuş ve Kazan'da çalışmış bir filolog olsa da Turgut Kut'un detaylı araştırmasına göre Kazan'da Nasreddin Hoca fikralarının ilk baskıları 1882-1910 yılları arasında yapılmıştır ve 1837 tarihli (İstanbul) Letâif baskısı kaynaklıdır. Kazan baskıları hem Batı dillerinde hem de Doğu Türkleri tarafından basılan Nasreddin Hoca eserlerinin tek kaynağı olmuştur (1997: 228). Zolotnitskiy'in eseri ise 1875 tarihlidir. Aksi olsaydı -ki daha eski baskıların ortaya çıkması her zaman mümkündür- söz konusu yazıda şamanlıkla ilgili olarak "kara inanç" 
ifadesi kullanan yazarın iyi bir Hristiyan olduğ ${ }^{13}$ da hesaba katıldığında bir Nasreddin Hoca fikrasını "aydınlatılması gereken kara halkın" eski geleneklerine karşı etkili bir araç olarak kullanmak üzere Çuvaş kültürüne uyarlamış olması fikri uzak bir ihtimal olmazdı. Sonuç olarak bu anlatı ister difüzyon isterse de gelişme yoluyla ortaya çıkmış olsun tam olarak Çuvaş kültürüne aittir.

Çuvaş folklorunda karşımıza çıkan diğer bir çeşitleme ise Yurkin'in 1907 yılında yayımladığı Halapsem (Skazki) [Masallar] adlı derleme eseri içinde yer alır. Kaynak kişisi, derlenme yeri ve zamanı hakkında hiçbir bilgi bulunmamaktadır. Özetlemek gerekirse, yaşlı bir adam odun kesmek için ormana gider ve bindiği dalı kesmeye başlar. Oradan geçen birisi düşeceği konusunda onu uyarır ama ihtiyar aldırış etmez. Az sonra ağaçtan düşer ve kendisini uyaran kişinin peşinden koşup ona, "Düşeceğimi bildin öleceğimi de bilirsin.” der. Eşeğinin üç kez yellendiğinde öleceği cevabını alan ihtiyar, odunları yüklediği eşeğiyle evine dönerken adamın söylediği gerçek olunca “İşte öldüm!” diyerek kendini yere atar. O sırada elma yüklü arabasıyla oradan geçen bir satıcının atı, yerde yatan adamdan ürker ve elma yüklü arabayı adamın üstüne devirir. Yerde yatan ihtiyar üstüne dökülen elmaları yemeye başlar. Dökülen elmalarını toplamaya çalışan satıcı ihtiyarın elmaları yediğini görünce ne yaptığını sorar ve "Ben öldüm, Tanrı beni cennetine aldı ve elma verdi." cevabını alır. Satıcının birkaç kırbaç darbesiyle dirilen yaşlı adam koşarak evine gider ve karısına, "Ben bugün ölüp cennete girdim, Tanrı bana orada elma yedirdi!” diye başına gelenleri anlatır (Yurkin, 1907: 5-6).

Bu çeşitleme, Tatar folklorundaki bir çeşitlemeyle neredeyse aynıdır. Öyle ki, neredeyse yerelleşme sürecine hiç girmemiş bu anlatı üzerinden Çuvaş folkloruna dair yapılacak her değerlendirme yanlış olacaktır. Tatarca çeşitlemedeki en önemli fark, Hoca'nın yediği dayaktan sonra canlanıp "Cennet nimetleri tatlımış ama kabir azabı acıymış!" (Özkan, 1999: 122-124) diyerek kaçmasıdır. Bu fark, Nasreddin Hoca adının yerini "yaşlı bir adam" ifadesinin almasından başka Çuvaşça çeşitlemedeki tek yerelleştirme unsuru olarak kabul edilebilir ki iki unsurun da inanış farklılığından kaynaklandığı açıktır. Çuvaşlarda kabir azabı gibi bir inanış olmadığı gibi cennet algısı da Hristiyanlıkla birlikte gelen ve yakın dönem halk anlatılarına bile derinlemesine nüfuz edemeyen bir olgudur. ${ }^{14}$ Belki de fikradaki bütün mizahın toplandığı odak noktası olan bu son cümlenin Çuvaş kültüründe tam olarak karşılık bulamaması fikranın çok fazla yerelleşmesine ve yayılmasına engel olmuştur. Diğer taraftan İdil-Ural bölgesinde yaygın olarak at kullanıldığı 1 ve halk anlatılarında neredeyse hiç eşekten bahsedilmediği hâlde hem Çuvaşça hem de Tatarca çeşitlemede eşeğin yer alması yazılı kaynaklarla olan organik ilişkisinin göstergesidir. Bir sonraki çeşitlemede yerelleştirmenin çok daha fazla olduğu görülecektir.

1952'de Vırmar rayonunda 68 yaşındaki İ. Afanasiyev'den derlenen diğer çeşitlemede ise kahraman artık yaşlı bir adam değil, Ahmak Yıvan (İvan)'dır. Yıvan diğer birçok çeşitlemede olduğu gibi odun kesmeye ormana gider, bindiği dalı keserken yaşlı bir adam tarafından uyarılır, düştüğünde "Düşeceğimi bildi ne zaman öleceğimi de bilir!” diyerek kendisini uyaran kişiyi öngörüde bulunması için sıkıştırır ve atının odun yüklü arabayla giderken üç kez durduğunda öleceği cevabını alır. Yolda at ağır yükü çekmekte zorlandığ1 için bir dereden geçerken öngörü gerçekleşince arabadaki odunların üstüne "Öldüm!” 
diyerek yatar. At ise biraz dinlenip odun yüklü araba ve Yıvan'la eve ulaşır. Karısı Yıvan’1 uyandırmaya çalıştığında, “Dokunma bana, ben öldüm!” der. İnsanlar toplanıp Yıvan’ı tabuta koyarlar, kilisede dua edip tabutu at arabasına yükleyerek gömmeye götürürler. Yıvan'ın öldüğünü sandığı dereye geldiklerinde insanlar bozuk köprüden mi yoksa başka köprüden mi geçeceklerini tartışırken Yıvan dayanamayıp "Ben kolay geçmiştim, başka yere gitmeyin. Buradan geçin!” deyince herkes kaçar. Akşama kadar burada kalan Yıvan, sonunda tabuttan çıkıp at arabasıyla evine döner. Yıvan kapıyı çalıp karısına "Aç kapıyı, ben senin kocanım.” dediyse de karısı, "Benim kocam öldü, bugün gömdüler. Sen "usal”sın, kocam kılığında beni kandırmaya çalışıyorsun.” der onu içeri almaz. O geceyi ahırın tepesinde geçiren Yıvan ertesi gün karısının komşulara gece olanları anlatmaya gittiği sırada eve girer ve oturup yemek yemeye başlar. Bu sırada karısı gelir, kocasını görünce korkup kaçar ve insanları toplar. İnsanlar bir şekilde cesaretini toplayıp içeri girerler ve onun gerçek Yıvan olduğunu anlarlar. Bütün olanları öğrendiklerinde Yıvan'a gülmeye başlarlar (Sidorova, 1976: 252-255).

Belirtmek gerekir ki bu çeşitleme bir öncekiyle aynı kaynağa dayanmıyor. Çünkü kahramanın ölüm haberini kendisinin getirmesi, cenazesinin kaldırılması ve tabutu taşıyanlara yol tarif etmesi bir önceki çeşitlemede yokken incelediğimiz diğer çeşitlemelerde ${ }^{15}$ sıkça görülmektedir ki bu çeşitlemelerin, Anadolu ve Nasreddin Hoca ile olan organik bağı açıktır. Bu şu anlama gelmektedir: Nasreddin Hoca fikralarının Çuvaş folkloruna teması tek kanaldan ya da bir kereye mahsus değildir. Son çeşitlemedeki yerelleştirme unsurları da gelenek içerisinde geçen uzun bir zamana işaret ediyor. O hâlde Çuvaşların hemen yanı başındaki Kazan Tatarları, Nasreddin Hoca geleneğinin hem kendi bölgesinde hem de Doğu Türkleri arasında yayılmasının temel müsebbibi görülürken Çuvaş folklorunda bu gelenek neden daha az gelişmiştir? Çeşitlemenin bu yeni bölgeye nasıl adapte ${ }^{16}$ edildiği incelendiğinde sorunun cevabı ortaya çıkacaktır.

$\mathrm{Bu}$ çeşitlemede kahramanın, tabutunu taşıyanlarla konuştuğu kısma kadar yapı ve motifler bakımından diğer çeşitlemelerden ayrılmadığı görülüyor. Çeşitlemenin devamı ise yerelleştirme sürecinin sonucudur. Asıl adaptasyon süreci burada görünmekle birlikte ilk kısımda da “yaşlı adam”ın yerini Ahmak Yıvan'ın alması ve cenazenin kiliseye götürülmesi, Rus kültürü ve Hristiyanlığın tesiridir ve yerelleştirme olarak kabul edilmelidir. Çuvaşların Hristiyanlaştırılması süreci, 1551 yılından itibaren devam etse de 1952 yılında kaydedilmiş olan bu son çeşitlemede geleneksel inanışların hâlen güçlü olduğu görülüyor. Dolayısıyla bu çeşitlemede kilisenin adından başka bir Hristiyan düşüncesine rastlanmaz. Ahmak İvan tipi de hem Keloğlan'dan hem de Rus folklorundaki İvan Durak'tan izler taşımaktadır. Belki daha da önemlisi bu çeşitleme bize Tatar ve Müslüman kültürünün Çuvaşlar üstündeki etkisinin, yerini Rus ve Hristiyan kültürüne bırakmakta olduğunu göstermesidir. Ancak çeşitlemenin diğer kısmı, tamamen Çuvaş geleneksel inanışları ve yaşayışıyla ilgilidir.

Çeşitlemede Yıvan'ın karısı tarafından "usal” sanılarak eve alınmaması, Çuvaş halk anlatılarında çok karşılaştığımız bir durumdur. Uygun görülmeyen bir ölüm biçimi ya da uygun görülmeyen aşırı yas tutma gibi durumlarda ölen kişi vireşilen, aştaha, yuhha ya da usal adı verilen varlıklara dönüşür ve bunlar hayattaki sevdiklerine musallat olurlar. Alt dünyada yeryüzündekine benzer bir hayat sürdüren ruhları sadece y1llık belli ritüellere davet edip 
besleyen Çuvaşlar için ölülerin beklenmedik gelişleri tehlikelidir. Yıvan'ın usal olmadığının anlaşılması ise mizahi açıdan da genel yapı bakımından da diğer çeşitlemelerden ayrılır ve anlam büyük oranda değişmiş olur. Nasreddin Hoca'nın cenazesinin söz konusu olduğu çeşitlemelerde olay ya "Ben sağ iken şu yoldan giderdim” şeklinde (Koz, 2015: 51) mizahi bir cümleyle ya da Hoca'nın, kabir azabıyla özdeşleştirilen bir dayakla kendine gelmesiyle (Boratav, 2006: 153; Duman, 2018: 242) biter. İlk biçim belki olabilir ama ikinci biçimin Çuvaş folklorunda yer bulabilmesi elbette beklenemez. Daha bütünlüklü olan ikinci biçim, aşağıda görüleceği üzere bu çeşitlemelerin simgesel anlamını -ölüp dirilme- görebilmemize imkân sağlamaktadır.

Hem çevre hem de gelenek morfolojisi açısından uyum sağlamış bir ekotip (büyük çeşitleme) olarak niteleyebileceğimiz bu anlatının da gösterdiği üzere Çuvaşların hem kendine özgü geleneksel inanışları hem de kültürel etkileşim kanalının yön değiştirmesi yerelleşme ve yayılma süreçlerinde olumsuz yönde etkili olmuştur. İslam düşüncesi içerisinde şekillenmiş bu çeşitleme yine de Çuvaş kültürüne girmiş, gelenek içerisinde uyarlanmış ve aktarılmıştır.

$\mathrm{Bu}$ anlatı tipinin Türkiye sahasında, Tatar, Kazak ve Özbek folklorunda karşılaştığımız kısa ya da uzun çeşitlemelerinde önemli sapmaların olmaması din faktörünün bu olgu üzerindeki belirleyici rolüne işaret etmektedir. Mesela Boratav'ın aktardığı iki çeşitleme oldukça kısadır. Bunlardan birinde Hoca eşine "Ölüyi neden bilürler?” diye sorar. Eşi de "Yüzi ve eli sovuk olur.” der. Dağa gittiği bir gün eli ve yüzü üşüyünce "Ben öldüm!” diye kendini yere atan Hoca'nın eşeğini o sırada kurtlar yer. Hoca yattığı yerden "Yegdür, yeg. Issı ölmiş eşek buldunuz, yemeye misiniz?" der (Boratav, 2006: 114-115). Bu çeşitlemede görüldüğü gibi sadece ölüme delalet sayılan mantıksız belirtilerin görülmesi, öldüğünü sanma, cezalandırılma (eşeğini kurtların yemesi) motifleri vardır. Diğer kısa çeşitlemede de sadece bindiği dalı kesme, ölüme delalet sayılan belirtiler ve öldüğünü sanma motifleri vardır (Boratav, 2006: 115). Bunlara çok benzer bir Özbek çeşitlemesinde de üşümeyi ölüm belirtisi sanan Hoca öldüğünü düşünüp kendini yere atar. Ormanda onu bulan oduncular tarafindan evine götürülürken köprü olmadığı için nereden geçeceklerini bilemeyen odunculara başını kaldırıp "Ben sağ iken hep şuradan geçerdim.” (Karakaş, 2000: 297) der. Kazak folklorunda ise oldukça geniş bir çeşitlemeye rastlıyoruz. Kocanasır adına bağlanan bu çeşitlemede bindiği dalı kesme, akıl dışı ölüm belirtisi (atın üç kez tökezlemesi), öldüğünü sanma (köprüde), sorgu meleği sanılan kervancılardan dayak yeme ve kendine gelme (cezalandırılma ve canlanma) gibi en yaygın unsurlara ek olarak kamçıyla döverek gerçek bir ölüyü canlandırmaya çalışması ve yine dayak yemesi söz konusudur (Duymaz-Aça-Arıkan, 2004: 136-138). Tatar folklorunda karşılaştığımız ikinci bir çeşitlemede de mezara girip öldüğünü sanan Hoca'nın hırsızlar tarafından soyularak dövülmek suretiyle cezalandırılması/canlandırılması (Özkan, 1999: 129-131) dişında farklılık yoktur.

\section{Gelenek tarihi boyutu}

Ele aldığımız anlatı tipinin çeşitlemelerinde karşılaştığımız temel motiflerin Türk Dünyası'nda olduğu kadar Hint coğrafyasındaki benzer anlatılarda ${ }^{17}$ da karşımıza çıktığını 
söylemiştik. Günümüz Pakistan'ı bu iki dünya arasında bir kesişme noktası olmasının yanı sıra tarihî süreçte siyasi ve kültürel temaslar bakımdan Türk kültür ekolojisinin dışında olmamıştır. Pakistan'ın Bannu bölgesinde 1874 yılında, bölgeye giden S. S. Thorburn tarafından Peştunlar arasında derlenmiş ve 1876 yılında aynı kişinin Bannu'yla ilgili monografisi içerisinde İngilizceye çevrilerek yayımlanan anlatı dikkat çekicidir. Bununla birlikte anlatının yaratıcısı olan Peştunların Türk Dünyasıyla genetik bir ilişkisi ya da dil akrabalığının bulunmaması olgunun gelenek tarihi (tradition history) boyutuyla incelenmesini gerektirir. Burada çeşitlemenin kaynağına dönük bir sorgulama yoluna gitmeyecek ve çeşitlemeyi yerelleştirme bağlamında değerlendireceğiz.

Eserin birinci kısmında verilen bilgilere göre Bannu halkı, birçok farklı Afgan kabilesinin birleşiminden meydana gelmektedir. Melik (Malik) denilen kabile reisleri tarafından yönetilen bu topluluk arasında dört sosyal sınıf vardır. Bunlardan biri melez ve her bakımdan kötü durumda olan köylülerdir. Diğer sınıf ise çok fazla batıl inanışa sahip ve halk1 sömüren dinî karakterlerdir (seyit, gazi, pir, molla). Müslüman işçileri sürekli aldatan Hindu tüccarlar üçüncü gruptur. Son grupta kısmen göçebe, kısmen çiftçi olan Veziriler bulunmaktadır (Thornburn, 1876: 35-41). Özetleyeceğimiz çeşitleme, bu sosyal tabakaların meydana getirdiği kültürel çevre tarafından şekillendirilmiştir.

Çeşitlemenin başkahramanı Hint coğrafyasında dokumacı ahmak bir tip olarak karşımıza çıkmaktadır. ${ }^{18}$ Dokumacı tıpkı Nasreddin Hoca gibi odun kesmeye gider ve kendi oturduğu dalı keserken oradan geçen bir Seyit tarafından düşeceği konusunda uyarılır. Öngörü gerçekleşince adamın peygamber olduğunu düşünen dokumacı, ne zaman öleceğini de söylemesini ister. Seyit de adamın ahmak olduğunu anlayıp "Hava çıktığı zaman." cevabını verir. Akşam yemeğinden sonra gayriihtiyari biçimde geğiren adam birden Seyid'in dediğini hatırlar. Eşine ve çocuklarına mezarını ve kefenini hazırlamalarını söyler. Kaliteli bir kefene konulan dokumacı mezarlığa götürülür. Defin sırasında dokumacının canlı olduğunu anlayan Molla, eve gittiğinde durumu kardeşine anlatır ve bir plan yaparlar. Gece mezarında hâlâ yaşam ve ölüm arasındaki farkı anlamaya çalışan dokumacının yanına gölge gibi iki kişi gelir. Münker ve Nekir olduklarını, onu sorgulamaya geldiklerini ve ölü olmadığı için kefenini vermek zorunda olduğunu söylerler. Bir süre sonra dokumacı korkuyu atlatır ve çıplak bir şekilde eve dönerken Seyid'in sözünü yanlış anladığının farkına varır (Thorburn, 1876: 206-207).

Nasreddin Hoca'nın bir şekilde kabre girmesi, Münker ve Nekir'i beklerken sesler duyup dışarı çıkarak çoban ya da kervancıların hayvanlarını korkutması ve bu nedenle dayak yemesi sık görülen durumlardır. Hırsızlık ise Tatarca çeşitlemede benzer bir şekilde karşımıza çıkmaktadır (Özkan, 1999: 129-131). Dolayısıyla Peştunca çeşitlemenin Türk Dünyası'ndaki benzerlerinden dokumacı ve seyit tipi dışında farkı yoktur. Söz konusu farklılıklar ise alt katman (substrate) özellikleri olup üst katman (superstrate) özelliklerine başarılı bir şekilde adapte edilmiştir. O hâlde Çuvaşlarda gelenek içerisinde yerelleştirmeye giren çeşitlemede neden üst yapı özellikleri kaybedilmiştir? Çünkü Peştunlar İslami düşüncenin ölüm sonrası inanışlarını bilmekte ve sürdürmektedirler. Bu bağlamda Peştunlar Türkiye sahası Türkler, Kazan Tatarları, Kazaklar ve Özbekler gibi Türk topluluklarıyla ortak bir 
noktayı paylaşmaktadırlar. Elbette bu durum Peştunların Türk kültürüne Çuvaşlardan daha yakın bir kültüre sahip olduğu anlamına gelemez. Çuvaşların dil, kültür, mitoloji ve tarih vd. bakımından Türk Dünyası içindeki yeri zaten bellidir. ${ }^{19}$ Farklılıkların kültürel unsurlar üzerindeki etkisini anlamak ise ancak bunların yaratıcı ve aktarıcılarını daha iyi tanımamızı sağlar ve yanlış değerlendirmeler yapmamıza engel olur. Çuvaş folklorunun Nasreddin Hoca fikralarına yabancı olmadığını tarihî ve kültürel ilişkiler temelinde tespit edip açıklamak, Çuvaşların Türk Dünyası içerisindeki yerini daha gerçekçi bir şekilde ortaya koymaya hizmet eder. Burada tek bir örnek üzerinden yapılan değerlendirmeler, olguların sosyokültürel ve çevresel faktörlerle nasıl şekillendiği açıklamaya yöneliktir.

\section{Fenomenolojik boyut}

Ele aldığımız çeşitlemeleri insanın evrensel karakteristiğinin bir sonucu olarak fenomenolojik bağlamda değerlendirmeye geçmeden önce iki örneğe daha yer vermek istiyoruz. ${ }^{20}$ Bunlardan ilki Paramartha Guru adındaki bir Budist rahip ve onun beş öğrencisinin ${ }^{21}$ gülünç ve akıl dışı maceralarından oluşan oldukça uzun bir anlatıdır. İlk kez Tamil dilinde İtalyan misyoner C. Giuseppe Beschi tarafından derlenen bu hikâyenin ${ }^{22}$ uydurma olduğu ve Brahmanların geleneklerini aşağılamak amacı güttüğü düşünülse de aynı hikâyeyi Fransızca yayımlayan bir başka misyoner J. A. Dubois, Beschi'nin gitmediği başka bölgelerde de aynı hikâyeyle karşılaştığını ve bunun Hint kökenli olduğu konusunda şüphesinin olmadığını yazar (1826: XV).

Anlatı uzun olduğu için sadece konumuzla ilgili kısımlarına temas edeceğiz. Paramarta Guru, diğer Hindu gurular gibi sürekli seyahat etmekte ve yaşamın gerçek anlamını sorguladığı bu yolculuklarda kendisi gibi ahmak olan öğrencileriyle birlikte komik ve akıl dişı maceralar yaşamaktadır. Böyle bir yolculukta kendisine hediye edilen at için ahır yapmaya karar verilir ve öğrencilerden biri ağaç kesmek için ormana gider. Öğrenci tutunduğu dalı keserken oradan geçen bir Brahman düşeceğini tahmin eder. Öğrenci de üstün bir bilge olduğunu düşündüğü Brahman'a yaşlı gurularının ne zaman öleceğini sorar. Brahman'ın cevabı ise "Sırt soğuduğunda, ölüm yanında!” şeklinde olur. Öğrenci diğer arkadaşlarıyla ve guruyla bu tahmini paylaştığında hepsi Brahman’a hayran kalır. Guru, bir daha ayaklarını bile yıkamamaya karar verir. Bir gece şiddetli bir yağmurda çatıdan akan yağmur Guru'nun yatağını 1slatır. Sabah uyandığında ıslak ve üşümüş olduğunu gören Guru, öğrencilerine hazırlıkları yapmalarını söyler. Guru, tahminin gerçekleşmesini yemeden içmeden beklerken sonunda hâlsiz düşüp bayılır. Öğrencileri öldüğünü sanarak Guru’yu gömmek üzere yıkarken Guru kendine gelip kurtulmaya çalışır. Öğrenciler ölünün kötü ruhlar tarafından ele geçirildiğini sanarak mücadeleyi bırakmazlar ve sonunda Guru'yu gömerler. Brahman'ın sözlerini tekrar ederek ilahiler söylerler (Beschi, 1861: 127-174). Anlatının başka bir çeşitlemesinde ise öğrenciler kötü ruhları yenemeyeceğini anlayıp kaçarlar. Guru'yu daha önce ona atı hediye eden yaşlı adam sudan çıkarır. Guru bu adamın tavsiyeleri ve verdiği kitap sayesinde yaptığı hataları anlayarak bütün yaşam felsefesini değiştirir (URL-1).

Kalidas'a atfedilen anlatıda ise Hint düşünce ve dünya görüşüne göre gerçek bilgeliğe 
nasıl ulaşılabileceği konu edilir. Gerçekte cahil ve ahmak olan Kalidas, krallığın prensesi Vidyotma'ya uygun bir eş arayan Hintli bilginler tarafından tutunduğu dalı keserken bulunur. Kendilerini sürekli aşağılayan prensesten intikam almak isteyen bilginler ahmak Kalidas'1 ruhu ve kalbi arındırmak için yapılan birkaç günlük konuşmama orucunda (maun vrat) bir bilge diye tanıtır. Prenses, Kalidas'ın işaret diliyle yöneltilen sorulara anlamsızca verdiği tepkileri üstün bir bilgelik olarak yorumlar ve onunla evlenir. Ancak ilk konuştuğunda onu saraydan kovar. Kalidas birçok tapınağa gider ve yıllar sonra gerçek bir bilgin olarak döndüğü sarayda Vidyotma tarafından uygun eş olarak kabul edilir (Dubey, 2018: 62-64).

Türk Dünyası'nda karşılaştığımız Nasreddin Hoca çeşitlemeleriyle benzer motifleri benzer bağlamlarda paylaşan bu iki anlatının da bambaşka bir dünya görüşü, felsefe ve yaşayış biçimi tarafından şekillendirildiği anlatıların tamamı incelendiğinde daha net görülmektedir. Elbette bu konunun başka bir boyutudur. Ancak incelediğimiz bütün anlatılarda akıl dişı varsayımlardan kaynaklanan "öldüğünü sanma motifi” ve sonrasında gerçekliğe dönme durumu ortaktır. Sadece Kalidas örneği bunun dışındadır ama yine de simgesel bir ölüm -cahillikten bilgeliğe geçiş- ve yeniden diriliş burada da söz konusudur.

Yap1, doku ve hacim bakımından farklılaşabilen bu anlatılar, bir takım birim ve eş birimleri paylaşmaktadırlar. Alan Dundes, Propp metoduna dayanarak geliştirdiği "allomotif" kavramını ortaya koymuş ve bu kavramın simgelediği birimler arasındaki ilişkiyi incelemek ve yorumlamak için şöyle bir formül geliştirmiştir: $A=B, B=C$ ise $A=C$ (Dundes, 2007: 323). $\mathrm{Bu}$ formülü kendi örneklemimize uygulayacak olursak el ve yüz soğukluğu, yellenmek, geğirmek, atın durması yahut tökezlemesi gibi durumlar birer ölüm işareti olarak öngörülmüş ve kahramanlar da bunlara inanarak öldüğünü sanmışlardır. Öldüğünü sanma ve yeniden gerçekliğe dönme durumu ise bazen bir mezarda, bazen bir nehrin yanında veya üstündeki köprüde ya da tek bir örnekteki gibi -Paramartha Guru- yatakta ve suda gerçekleşmektedir. Bütün bu mekânların mitolojik bağlamda ana rahmiyle ilişkilendirildiği, dolayısıyla ölüm ve doğum arasında eşik/geçiş noktası teşkil ettiği bilinmektedir. Kahramanın gerçekliğe döndürülmesi ise kırbaçlanma, eşeğinin kurtlar tarafından yenmesi, hırsızlar tarafından soyulması ya da suyun içine sokulması gibi simgesel cezalandırma yöntemleriyle gerçekleştirilmektedir. Bindiği dalı kesmek ve akıl dışı öngörülere dayanarak hareket etmek ya da öldüğünü sanmak ise yine diğer eş birimler olarak kabul edilebilir. Dolayısıyla bütün bu anlatıların anlamını kısaca ölüm -gerçeklikten kopmak- ve cezalandırılarak yeniden doğmak -gerçekliğe dönmek- şeklinde özetleyebiliriz.

Eşik mekânlarda gerçekleşen bu olayların kahramanları da bir eşiktelik hâlindedirler. İster Mihail Bakhtin'in "karnavalesk"23 ister Victor Turner'ın (1977) “comunitas" kavramiyla açıklayalım, bu kahramanlar ahmaklık ve bilgelik, hayal ve gerçeklik, (toplumsal) yapı ve anti yapı arasındaki sınırları zorlarlar, mizahı ve eleştirel düşüncenin gücünü kullanarak karşıt yapılar ve roller arasındaki ilişkileri ortaya koyarlar. 


\section{Sonuç}

Kültürel olguların çok boyutlu özellikleri karşılaştırmalı çalışmaları zaruri kılmaktadır. $\mathrm{Bu}$ durum, araştırmaların çok yönlü ve analitik araçların esnek olmasını gerektirmektedir. Benzer şekilde verilerin de çağımızın şartlarına uygun bir şekilde karşılaştırmalı ve çok yönlü sorgulamalara elverişli, devamlı geliştirilmeye açık olan dijital bir ortamda bir araya getirilmesi gerekmektedir. Bu çalışmayı yaparken motif indeksi gibi eserlerin Türk Dünyası folkloru araştırmaları için ne kadar önemli olduğunu daha yakından gördügümüzü belirtmek gerekir. Bu sahada yapılacak çalışmaların bütünlüklü bir nitelik kazanması ve geleceğe taşınması için dijital çağın imkânlarından faydalanmak şarttır. Yöntem konusu da Türk Dünyası'na dönük olarak yapılacak çalışmaların ortak bir amaç, formasyon ve bilimsellik çerçevesinde sürdürülebilmesi için tartışılmaya devam edilmesi gereken önemli bir konu olarak önümüzde durmaktadır.

Kültürel olguların ekolojik, tarihî ve fenomenolojik gibi farklı boyutlarıyla karşılaştırmalı olarak incelenmesi parça, bütün ve evren ilişkisini ortaya çıkarmaktadır. Tür, tipoloji, varyant vd. gibi analitik kavramlar ve araçlar bazen söz konusu parça-bütün ilişkisini görmeye engel teşkil edebilmektedir. Bu bağlamda mikro ölçekteki ortaklıklara odaklanmak, bütüncül yaklaşımlara ve çok boyutlu sorgulamalara imkân tanımaktadır. Nasreddin Hoca adını bütün Türk boylarının folklorunda göremeyeceğimiz gibi benzer anlatılarla fikra değil, masal ya da başka tür adları altında karşılaşabiliriz. Çuvaş folklorunda Nasreddin Hoca adıyla karşılaşmasak da benzer anlatıların ekolojik bağlamda incelenmesi Çuvaşlarla Türk Dünyası arasındaki ortaklık ve farklılıkların açıklanmasına yardımcı olmaktadır. İncelediğimiz tek bir örnek durum bile, Çuvaşların bu geleneğe yabancı olmadığını, farklı zamanlarda ve farklı kaynaklardan Nasreddin Hoca geleneğiyle temas etmiş olduğunu, birtakım anlatıları kendi gelenekleri içinde nasıl biçimlendirdiklerini ve sonrasında farklı bir kültürel etki alanına girmiş olduklarını göstermiştir. Aynı şekilde örneklemimizde din faktörünün belirleyici rolü de açık bir şekilde görülmektedir.

Diğer taraftan farklı kültürlerde benzer olgularla karşılaşılabileceği gerçeği de gözden uzak tutulmamalıdır. Bu çerçevede yapılacak karşılaştırmalar kültürel ilişkileri ve evrensel insan özelliklerini ortaya çıkarması bakımından önemlidir. Bilgelik ve ahmaklık, yaşam ve ölüm, ideal ve gerçek, düzen ve düzensizlik gibi konular bütün insanlığın üstünde düşündükleri meselelerdir. Bunların yorumlanış biçimi, sıklığı ve miktarı ise kültürlere özgün niteliklerini kazandırmaktadır.

\section{Notlar}

1 Buna rağmen başlıkta söz konusu deyimin kullanılmasının nedeni, çalışmanın içeriği ve çıkış noktasıyla ilgili okuyucuya hemen başlıkta fikir verebilme ihtiyacıdır. İngilizce başlıkta ise deyimin doğrudan karşılığı değil, masal tipleri kataloğunda (Aarne-Thompson 1961: 378) çalışmanın konusu olan anlatı tipinin başlığı kullanılmıştır.

2 Bütüncül yaklaşımla ilgili ayrıca bk. Bayram 2019; Bayram 2020.

3 Nasreddin Hoca anlatılarının yayılma sahaları ve biçimleri hakkında daha geniş bilgi için bk. Kut 1986; Türkmen 1987; Boratav 2006. 
4 Honko'nun "kültürel çevre" (cultural periphery) ya da "kültürel alan" (cultural area) şeklinde nitelediği bu bölgeler, çeşitlenme ve yerelleştirme (ecotypification) odaklı sonraki çalışmalarda "temas alanı" (contact zone) olarak adlandırılmış ve asimetrik güçlere sahip toplulukların mücadele ettiği sosyal evren anlamında kullanılmıştır (Bk. Pratt 1991; Hasan-Rokem 2016).

5 İsveçli folklorcu Carl Wilhelm von Sydow, botanik bilimine ait olan "oicotype" (ecotype) terimini geleneğin yayılması bağlamında miras alınan bir formun belirli bir bölgeye adapte edilmiş, doğal ve canlı bir bütünün parçası anlamında kullanarak masal çalışmalarına dâhil etmiştir. Günümüze kadar etkin bir şekilde geliştirilerek kullanılan bu terime dayalı olarak yapılmış çalışmalar hakkında bilgi için bk. Hasan-Rokem 2016.

6 Çuvaşlar Rus hâkimiyeti altına girene kadar, komşuları olan Fin-Ugor halkı Mariler üzerinde dil bakımından üst katman etkisine sahipken sonradan bu etki yan katman düzeyine evrilmiştir (Durmuş 2012: 178). Çuvaşlarla Mariler arasındaki kültürel ilişkilerin durumu da aynı doğrultuda kabul edilebilir.

7 Balkan coğrafyasındaki Nasreddin Hoca geleneğiyle ilgili Wesselski (1911) ve Vılçev (1975) tarafından hazırlanan iki eser oldukça önemlidir. Bu eserlerle ilgili değerlendirmeler için bk. Acaroğlu 1996; Boratav 2006.

8 Konuyla ilgili bk. Toska 1989; Kut 1997.

9 Pertev Naili Boratav'ın “Nasreddin Hoca Fıkraları İçin Bir Kaynak Kitap Tasarısı” başlıklı yazısı bu bağlamda zamanının şartlarına göre oldukça ileri görüşlü fikirler sunmaktadır. Boratav bu yazıda ileride gerçekleştirilmesi gereken "Türk Halk Fıkraları Kataloğu”nun ilk aşaması olarak Nasreddin Hoca adını bile taşımayan, yabancı dillerdeki örnekleri de kapsayan bir eserin nasıl olması gerektiğini 1975 yılında detaylarıyla açıklamıştır (2006: 49-55). Bahsettiğimiz veri tabanı için bu tasarı iyi bir başlangıç noktasıdır. Elbette bu tasarının günümüz şartlarına göre güncellenmesi gerekecektir.

10 Pertev Naili Boratav'ın bu konuda bir istisna olduğunu belirtmek gerekir.

11 Nasreddin Hoca'nın Slav topluluklarındaki edebî uyarlamaları için bk. Sabatos 2016.

12 Çuvaşların yumzalar, kötü ruhlar ve hastalıklarla ilgili inanışları hakkında detaylı bilgi için bk. Timofeyev 2002: 46-56.

13 Zolotnitskiy'in Çuvaş Knege (1980) adlı eseri, Çuvaş alfabesi oluşturmaya dönük ilk ciddi deneme kabul edilmekte ve Hristiyan öğretisine dayalı metinlerden oluşmaktadır.

14 Çuvaşlarda ölümle ilgili pratik ve inanışlar incelendiğinde mezarın ve öteki dünyanın yeryüzündeki yaşamın bir çeşit yansıması gibi algılandığı görülmektedir. Geniş bilgi için bk. Yegorov 1995; Yavuz 2019.

15 Duman 2018: 243, 340; Boratav 2006: 172; Koz 2015: 51.

16 Lauri Honko, bir geleneğin adaptasyonunun üç farklı şekilde gerçekleşebileceğini yazar. Bunlar; çevre morfolojisine adaptasyon (milieu-morphological adaptation), gelenek morfolojisine adaptasyon (tradition-morphological adaptation) ve işlevsel adaptasyon (functional adaptation). Birincisi toplumu ve geleneğini şekillendiren doğal çevreye (mekân), ikincisi toplumun onayladığı kolektif değerlere dayalı adaptasyonu kapsar. Diğeri adapte edilen geleneğin icra ortamında kazandığı anlam ve işlevlere dairdir. Honko ilk iki süreçteki çeşitlemelere büyük çeşitleme (major/great variation), diğerine ise küçük çeşitleme (small/minor variation) adını verir. Bu sürecin birleşik etkilerine yerelleştirme (ecotypification) denir (1986: 119-120).

$17 \mathrm{Bu}$ temel motiflerin ortaklığı, anlatılar arasındaki yapısal, sosyokültürel ve düşünce biçimi fark- 
lılıklarını elbette ortadan kaldırmamaktadır. Anlatıların içeriğiyle ilgili genel bilgi için bk. Parker 1914: 74-75.

18 Krş. Dubois 1826; Luomala 1966; Parker 1914.

19 Çuvaşların Türk Dünyası içerisindeki yerinin kültürel süreklilikler bağlamında bir değerlendirilmesi için bk. Bayram 2019b.

20 Seylan bölgesinden derlenmiş, benzer motifleri içeren bir anlatı için bk. Parker 1914: 70-75.

21 Öğrencilerin adları da hikâyelerle örtüşmektedir: Moodan (Aptal), Matti (Budala), Madayan (Salak), Paedhai (İdiot), Milaechan (Embesil) (Pandian 2019: 363).

22 C. G. Beschi'nin ortaya çıkardığı bu anlatı 1822'den itibaren İngilizce ve diğer dillere çok kez çevrilmiş, ayrı ya da Pançatantra kitapları içinde yayımlanmıştır. Genel karşılaştırma yapılırsa anlatının Pançatantra'nın son kitabıyla tematik olarak uyuştuğu görülmektedir. Pançatantra'nın çevirilerinin çok farklı metinlere dayanması sebebiyle olsa gerek bütün yayımlarda bu anlatıyla karşılaşmıyoruz. Pançatantra'nın Türkçeye yapılan yeni bir çevirisinde de bulunmuyor (Vishnusarman 2020). Bu çalışmada Beschi'nin 1861 yılı çevirisini kullandık.

23 Bu bağlamda fikralarla ilgili yapılmış şu çalışmalara bakılabilir: Petzen 1996; Erdoğan 2013; Gülüm 2016, Sabatos 2016. Bu ikiliklerin eleştirel düşünce ve bilgelik arasındaki ilişkisi bağlamında bir değerlendirme için bk. Özdemir 2010.

\section{Kaynakça}

Aarne, A., \& Thompson, S. (1961). The types of the folktale. Helsinki: Academia Scientiarum Fennica.

Acaroğlu, M. T. (1996). Nasreddin Hoca ile Kurnaz Peter üzerine kapsamlı bir araştırma (M. S. Koz, Düz.) Nasreddin Hoca'ya Armağan ( 15-38). İstanbul: Oğlak Armağan Kitaplar. Aça, M. (2000). Türk destancılık geleneğine bütüncül yaklaşabilme ve alp kavramı üzerine bazı yeni yaklaşım denemeleri. Millî Folklor, 48, 5-17.

Bayram, B. (2019a). Siyasi sınırların kültür araştırmalarına etkileri üzerine bir değerlendirme. Tyurkologiyata v obrazovaniyeto-Traditsii, inovatsii, perspektivi ( 4-15). Şumen: Şumenski universitet Yepiskop Konstantin Preslavski.

Bayram, B. (2019b). Türk Bitig Türklük Bilimi araştırmaları Kırklareli Üniversitesi çağdaş Türk lehçeleri ve edebiyatları bölümü yıllı̆̆ı (1-17). Çanakkale: Paradigma Akademi.

Bayram, B. (2020). Türkistan coğrafyasında yeni bir Türkoloji inşası üzerine düşünceler. VI Orazov okuvlarl: Sandık Devirdegi Türki medeniyetinin özekti meleseleri (Halıkaralık gllımi-tejiribelik konferentsiya enbekter jinagl (171-176). Şımkent: Silkway Halıkaralık Universiteti.

Beschi, C. G. (1861). The strange surprising adventures of the venerable Gooroo Simple (B. Babington, Çev.) London: Trubner \& Co.

Boratav, P. N. (2006). Nasreddin Hoca. İstanbul: Kırmızı.

Constantin, G. I. (1972). Nasreddin Khodja chez les Tchouvaches: Mikhail Yuhma: Cveti El'bi, rasskazky, skazki, legendy. Turcica Revue d'Etudes Turques, 4, 171-181.

Çulgaş, K. (1939). Lapşu Ştappani. Şupaşkar: ÇASSR Gosudarstvo İzdatel'stvi. 
Dubey, A. (2018). Communication and literature: An analysis through the tale of Indian poet Kalidas and his wife, Widyotma. American International Journal of Research in Humanities, Arts and Social Sciences, 21 (1), 62-64.

Dubois, J. A. (1826). Le pantcha-tantra. Paris: J. S. Merlin.

Duman, M. (2018). Nasreddin Hoca ve 1616 fikrast. İstanbul: Everest.

Dundes, A. (2007). The meaning of folklore: the analytical essays of Alan Dundes (S. J. Bronner, Ed.) Utah: Utah State University.

Durmuş, O. (2012). Çuvaş-Mari dil ilişkilerine genel bir bakış I: (Çuvaşçanın Mariceye etkisi). Türk Moğol araştırmaları - Prof. Dr. Tuncer Gülensoy armă̆anı (153-168). Ankara: Türk Kültürünü Araştırma Enstitüsü.

Duymaz, A., Aça, M., \& Arıkan, M. (2004). Kazak halk edebiyatı. Başlangıcından günümüze kadar Türkiye dışındaki Türk edebiyatları antolojisi (nesir-nazım)-Kazak edebiyatı I ( 27, 136-138). Ankara: T.C. Kültür ve Turizm Bakanlığg1.

Ekici, M. (1998). Halk bilimi çalışmalarında metin (text), doku (texture), sosyal çevre ve şartlar (konteks) ilişkisinin önemi. Millî Folklor, 39, 25-34.

Erdoğan, N. (2013). Nasreddin Hoca and Tamerlane: Encounters with power in the Turkish folk tradition of laughter. Revista de Etnografie si Folclor/Journal of Ethnography and Folklore, (1-2), 21-36.

Görkem, İ. (2012). Nasreddin Hoca olgusunun algılanması ve anlamlandırılması üzerine. Türkbilig, 23, 83-106.

Gülüm, E. (2016). Karnavalesk bir imgelemin taşıyıcısı olarak Bektaşi mizahı. Millı̂ Folklor, $112,130-141$.

Güngül, G. (1995). Türk dünyasında Nasreddin Hoca. Türk Edebiyatı, 255, 62-63.

Hasan-Rokem, G. (2016). Ecotypes: Theory of the lived and narrated experience. Narrative Culture, 3 (1), 110-137.

Honko, L. (1986). Types of comparison and forms of variation. Journal of Folklore Research, $23(2 / 3), 105-124$.

Ilyefalvi, E. (2017). Textualization strategies, typological attemps, digital databases: what is the future of comparative charm scholarship? Incantatio. An International Journal on Charms, Charmers and Charming, 6, 37-77.

Johanson, L. (2001). Türk dünyasının sınırları: Türk topluluklarının gelişmesinde bağlayıcı ve ayırıcı unsurlar. Türkbilig, 2, 168-177.

Kaçalin, M. S. (1997). Kıyıda kalmış birkaç lâtife. Toplumbilim, 6, 105-106.

Karakaş, Ş. (2000). Özbek halk edebiyatı. Başlangıcından günümüze kadar Türkiye dışındaki Türk edebiyatları antolojisi (nesir-nazım)-Özbek edebiyatı I (14, 297). Ankara: T.C. Kültür Bakanlığı.

Koz, M. S. (Haz.). (2015). Letâ'if (Nasreddin Hoca Fıkralarının İlk Baskısı). İstanbul: Büyüyenay.

Köprülü, M. F. (2004). Nasreddin Hoca. Ankara: Akçă̆. 
Kut, G. (1997). Hint edebiyatından Türk hikâyelerine. Türklük Araştırmaları Dergisi, 8, 357377.

Kut, T. (1986). Nasreddin Hoca fikra kitaplarının Kazan baskıları. III. Milletlerarası Türk folklor kongresi bildirileri: Halk edebiyatı (Cilt II, s. 221-230). Ankara: Kültür ve Turizm Bakanlığı Millî Folklor Araştırma Dairesi.

Luomala, K. (1966). Numskull clans and tales: Their structure and function in asymmetrical joking relationships. Journal of American Folklore, 79 (311), 157-194.

Oğuz, M. Ö. (1991). Türk dünyası folklorunda yeni yöntem arayışları. Millî Folklor, 33, 3-8.

Oğuz, M. Ö. (1999). Türk halkbilimi çalışmalarında eşmetin (varyant) ve benzer metin (versiyon) sorunu. Millî Folklor, 42, 2-5.

Oğuz, M. Ö. (2000). Türk dünyası halk biliminde yöntem sorunları. Ankara: Akçağ.

Öğ̈̈t-Eker, G. (2005). Nasrettin Hodja in the Turkic world. International Journal of Central Asian Studies, 10(1), 34-53.

Özdemir, N. (2010). Mizah, eleştirel düşünce ve bilgelik: Nasreddin Hoca. Millî Folklor, 87, $27-40$.

Özkan, İ. (1999). Türkiye ve Tatar Türkçesiyle Nasreddin Hoca fikralarl. Ankara: TİKA.

Pandian, M. R. (2019). Humor in depicting apostles of Jesus and disciples of Paramartha Guru. Research Journal of English Language and Literature, 7(3), 361-367.

Parker, H. (1914). Village folk-tales of Seylon (Cilt 2). London: Luzac \& Co.

Petzen, J. (1996). Nasreddin Hoca fikralarında güç, beden ve toplumsal cinsiyet kavramları. Kebikeç, 4, 7-12.

Pratt, M. L. (1991). Arts of the contact zone. Modern Language Association, 33-40.

Sabatos, C. (2016). Nasreddin Hodja's foolish wisdom: Slavic literary adaptations of a Turkish hero. World Literature Studies, 8(4), 35-46.

Sakaoğlu, S., \& Alptekin, A. B. (2009). Nasredin Hoca. Ankara: Atatürk Kültür Merkezi.

Sidorova, Y. S. (1976). Çı̌vaş Halı̆h Sümahlı̌h|. Yumahsem. Şupaşkar: Çıvaş Kineke İzdatel'stvi.

Thompson, S. (1958). Motif-index of folk literature: A classification of narrative elements in folktales, ballads, myths, fables, mediaeval romances, exempla, fabliaux, jest-books and local legends. Bloomington: Indiana University.

Thorburn, S. S. (1876). Bannu: Our Afghan frontier. London: Trübner \& Co.

Timofeyev, G. T. (2002). Tǐhı̌r'yal. S|ve tǐrşşsinçi ç̌̌vaşsem. Şupaşkar: ÇKİ.

Toska, Z. (1989). Türk edebiyatında Kelile ve Dimne çevirileri ve Kul Mesûd çevirisi. İstanbul Üniversitesi Sosyal Bilimler Enstitüsü Yayımlanmamış Doktora Tezi.

Turner, V. W. (1977). The ritual process (structure and anti-structure). New York: Cornell University.

Türkmen, F. (1987). Nasreddin Hoca fikralarının yayılma sahaları. I. Uluslararası Türk halk 
edebiyatı semineri ( 349-359). Eskişehir: Yunus Emre Kültür Sanat ve Turizm Vakfi.

Vılçev, V. (1975). Hitır Petır i Nastradin Hoca, iz istoriyata na bılgarskiya naroden anekdot. Sofiya: İzdatelstvo Na Blgarskata Akademiya Na Naukite.

Vishnusarman. (2020). Pançatantra (H. D. Can, Çev.) İstanbul: Ötüken.

Wesselski, A. (1911). Der Hodscha Nasreddin. Türkische, berberische, maltesische, kalabrische, kroatische, serbische und griechische Märlein und Schwänke. Weimar: Duncker.

Yavuz, C. (2019). Çuvaş kültür mitleri. Uluslararası toplum ve kültür araştırmaları sempozyumu (3-5 Ekim 2019) tam metin bildiler kitabı (M. Aça. Ed.) ( 441-464.). Çanakkale: Toplum ve Kültür Araştırmaları Derneği.

Yegorov, N. İ. (1995). Çuvaşskaya mifologiya. Kul'tura çuvaşskogo kraya. Çast I: Uçebnoye posobiye. (Haz. M. I. Skvortsov). ( 109-147). Çeboksarı: ÇKİ.

Yurkin, İ. N. (1907). Halapsem. Kazan: Tsentrralnaya Tipografiya.

Zolotnitskiy, N. İ. (1870). Çuvaş Knege. Kazan: Bratsva Sv. Guriya.

Zolotnitskiy, N. İ. (1875). Kornevoy çuvaşsko-russkiy slovar, sravnennıy s yazıkami i nareçiyami raznı narodov tyurskogo, finskogo i drugih plemen. Kazan: Tipografiya İmperatorkago Universiteta.

\section{Elektronik kaynaklar}

URL-1: Guru Paramartha and His Five Foolish Disciples. Erişim tarihi 02.12.2020, https:// www.indiadivine.org/guru-paramartha-and-his-five-foolish-disciples/

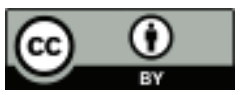

Bu eser Creative Commons Atıf 4.0 Uluslararası Lisansı ile lisanslanmıştır. (This work is licensed under a Creative Commons Attribution 4.0 International License). 